\title{
Effect of instruction and motivation in the use of electric and manual toothbrushes in periodontal patients. A comparative study
}

\section{Efeito da instrução e motivação no uso de escovas de dente elétrica e manual em pacientes periodontais. Um estudo comparativo}

\author{
Tove Roscher* \\ Cassiano Kuchenbecker Rösing** \\ Per Gjermo*** \\ Anne Merete Aass***
}

\begin{abstract}
The aim of the present study was to evaluate the efficacy of manual and electric toothbrushes in plaque control in periodontal patients after proper instructions. Thirty six periodontal patients (mean age of 49 years, 21 females and 15 males) were included and completed the study (100\% compliance). A single-blinded, randomized, controlled, cross-over clinical design was adopted, with the patients using during 2 periods of 14 days each the manual and/or electric toothbrush. Four subgroups of 9 individuals were studied: A1 - used manual toothbrush in both experimental periods; A2 - used the manual toothbrush during the first period and the electrical toothbrush during the second period; B1 - used electrical toothbrush during both periods; B2 - used the electrical toothbrush in the first period and the manual one in the second period. Brushing was performed during 14 days and at day 14 and 28 it was performed in the clinic, and timing of brushing was recorded without patients being aware. The Plaque Index (Silness, Löe, 1964) was used. Intra-group comparisons were performed by paired $t$-test and inter-group comparisons by independent sample $t$-test, with an alpha level of 0.05 . The results showed no difference between the tested brushes neither for plaque nor for timing. However, re-instruction was detected as an important factor, since for all groups the second period, after reinstruction, showed lower plaque scores. It is concluded that professional advice and instruction and re-instruction seem more important in order to obtain good plaque control than the choice of toothbrush in subjects with periodontal disease.
\end{abstract}

DESCRIPTORS: Periodontitis; Dental plaque; Toothbrushing.

\begin{abstract}
RESUMO: O objetivo do presente estudo foi avaliar a eficácia de escovas dentais manual e elétrica no controle de placa em pacientes periodontais após instruções apropriadas. Trinta e seis pacientes periodontais (média de idade de 49 anos, 21 mulheres e 15 homens) foram incluídos e completaram o estudo (100\% de adesão). Um delineamento de ensaio clínico randomizado controlado cego e cruzado foi adotado, com pacientes usando durante 2 períodos de 14 dias cada escovas manuais e/ou elétricas. Quatro subgrupos de 9 indivíduos foram estudados: A1 - utilizou escova manual em ambos os períodos experimentais; A2 - utilizou a escova manual durante o primeiro, e a escova elétrica, no segundo período; B1 - usou escova elétrica em ambos os períodos; B2 - iniciou com escova elétrica e utilizou escova manual no segundo período. A escovação foi realizada durante 14 dias e, nos dias 14 e 28 , essa foi realizada na clínica, e o tempo de escovação foi cronometrado sem que os pacientes soubessem. O Índice de Placa (Silness, Löe, 1964) foi utilizado. Comparações intragrupo foram realizadas por teste $t$ pareado e intergrupo por teste $t$ para amostras independentes, com um nivel alfa de 0,05 . Os resultados não identificaram diferenças entre as escovas testadas em relação à placa ou ao tempo utilizado. Entretanto, reinstrução foi detectada como um fator importante, uma vez que, para todos os grupos, o segundo período, após reinstrução, demonstrou menores escores de placa. Conclui-se que aconselhamento profissional e instrução e reinstrução parecem mais importantes para se obter um bom controle de placa do que a escolha da escova em pacientes com doença periodontal.
\end{abstract}

DESCRITORES: Periodontite; Placa dentária; Escovação dentária.

\footnotetext{
*DDS; *** PHD, DDS - Department of Periodontology, School of Dentistry, University of Oslo, Norway.

** DDS, Department of Periodontology, School of Dentistry, Federal University of Rio Grande do Sul.
} 
Roscher T, Rösing CK, Gjermo P, Aass AM. Effect of instruction and motivation in the use of electric and manual toothbrushes in periodontal patients. A comparative study. Braz Oral Res 2004;18(4):296-300.

\section{INTRODUCTION}

Regular complete removal of supragingival plaque is considered important for dental health; both in relation to dental caries and periodontal conditions $^{3}$ and as a prerequisite for long term success of periodontal treatment ${ }^{5}$.

Manual toothbrushes have been the most used tool for home-based oral hygiene procedures during the past century. More recently, electric toothbrushes have become more common and are often recommended for patients with reduced manual dexterity $^{6}$. Also, the use of electric toothbrushes seems to be increasing among people with no specific recommendation by oral health personnel.

However, published results from a series of studies comparing manual and electric brushes have yielded equivocal results $2,4,8-10,12-14$. Occasional statistically significant effects in favour of one or the other brush indicate that observed differences are small and with doubtful clinical importance.

For most electric toothbrushes, the user only guides the brush around the dentition. The mechanical action is provided by the powered mechanical movements of the bristles. This mode of brushing is different from the one used with a manual brush and it seems that proper instruction in how to use it in a particular situation is mandatory.

One study has demonstrated a "learning curve" when introducing an electric toothbrush, probably due to the different method of action as compared with conventional manual brushes, and indicates that a period of 2 weeks is necessary to obtain reasonably good command ${ }^{12}$.

In periodontal care, proper mechanical tooth cleaning is crucial, and a substantial amount of time is spent in order to motivate and teach patients to obtain optimal everyday control of plaque accumulation. The potential of electric brushes for this purpose has not been extensively investigated, especially concerning the educational process, which involves instruction and re-instruction.

The aim of the present study was to test the hypothesis that manual and electric toothbrushes are equally efficacious for plaque control in periodontal patients after proper instructions.

\section{MATERIAL AND METHODS Test panel}

The study participants were recruited among patients in the age range 26-64 (mean $=49$ years, 21 females and 15 males) with 18 or more remaining teeth, referred to the Institute of Clinical Den- tistry, School of Dentistry, University of Oslo, for periodontal treatment. Thirty six patients were included in the trial.

\section{Exclusion criteria}

Participants who had received antibiotic treatment during the last three months, had made daily use of any drug that could influence in plaque formation, had any handicap that might interfere with the brushing technique or had less than $15 \%$ of buccal or lingual surfaces with visible plaque at admission were excluded.

The Ethics Committee of Health, Oslo, Norway, approved the study.

\section{Test brushes}

The electric brush tested was Philips Jordan Sensiflex (Philips Jordan Inc., Amsterdam, Netherlands), with a separate moving active tip and a controlled pressure system whereby the brush head flexes back, making the user aware whenever "excessive" forces are being used (Philips Jordan Inc., Amsterdam, Netherlands). As manual control, the Butler 411 toothbrush was chosen (The John O. Butler Company, Ottawa, Canada).

\section{Clinical examinations}

Plaque was assessed according to the Plaque Index (P1.I) ${ }^{7}$ and scored after two and four weeks on 6 surfaces of all present teeth-mesiobuccal, midbuccal, distobuccal, mesiolingual, midlingual and distolingual. Also, pontics of fixed bridges were clearly identified in the charts and scored as teeth.

During the experimental period, no other mechanical or chemical means of oral hygiene than the experimental brushes were used and all the participants used the same brand of toothpaste, Solidox F (Solidox Inc., Oslo, Norway). The participants were recommended to brush their teeth twice a day, in the morning and in the evening, for two minutes each time according to detailed chair-side instructions.

Adverse effects were assessed according to ADA (American Dental Association) specifications as follows: the mucous membranes of the tongue, the hard and the soft palate, the gingiva, the mucobuccal folds, the inner surfaces of the cheeks and sublingual space areas were inspected separately for abnormal appearances and recorded as positive 
Roscher T, Rösing CK, Gjermo P, Aass AM. Effect of instruction and motivation in the use of electric and manual toothbrushes in periodontal patients. A comparative study. Braz Oral Res 2004;18(4):296-300.

or negative. If positive observations were recorded, colour photos were taken.

The plaque scoring was performed by one examiner (who was blind to the brush employed) throughout the study. Random double scoring of approximately $10 \%$ of the participants enrolled in the study was employed for assessing reliability.

Reproducibility of the plaque index assessed as agreement on the visible plaque level was $98.7 \%$.

\section{Study design}

The study was carried out as a single-blinded cross-over clinical trial (Figure 1). At the start of each experimental period, all the participants received supragingival professional toothcleaning. At the day of scoring, brushing was not performed in the morning. The participants brushed their teeth immediately before scoring, and the entire time used for brushing was recorded (without the participant's awareness).

\section{Examining schedule Baseline}

Initial plaque registration and exclusion of non-eligible individuals, professional cleaning and random group allocation were performed. Group A received information about periodontitis with emphasis on home-based oral hygiene and instruction in effective plaque removal by means of a manual toothbrush (Butler 411). Group B received the same information, but was instructed in the use of an electric toothbrush (Philips Jordan Sensiflex). All the participants received oral and written instructions for the recommended procedure. In addition, the methods were demonstrated on models as well as in the participants' mouths.

\section{Two-week follow-up}

After plaque registration, group A was randomly subdivided into two subgroups. Subgroup A1 was re-instructed in the use of the manual brush, emphasizing areas with unsatisfactory plaque control, and continued to use the same brush. Subgroup A2 received instructions in the use of the electric brush according to the protocol used at the start of the study, and switched to this brush. Similarly, group B participants were reallocated into subgroups B1 and B2. Subgroup B1 received re-instructions with the electrical brush with emphasis on areas with unsatisfactory plaque control, and continued to use this brush. Subgroup B2 switched to the manual brush after having received proper instruction.

\section{Four-week follow-up}

Recording of Pl.I was performed and all the procedures were the same as in the two-week follow-up.

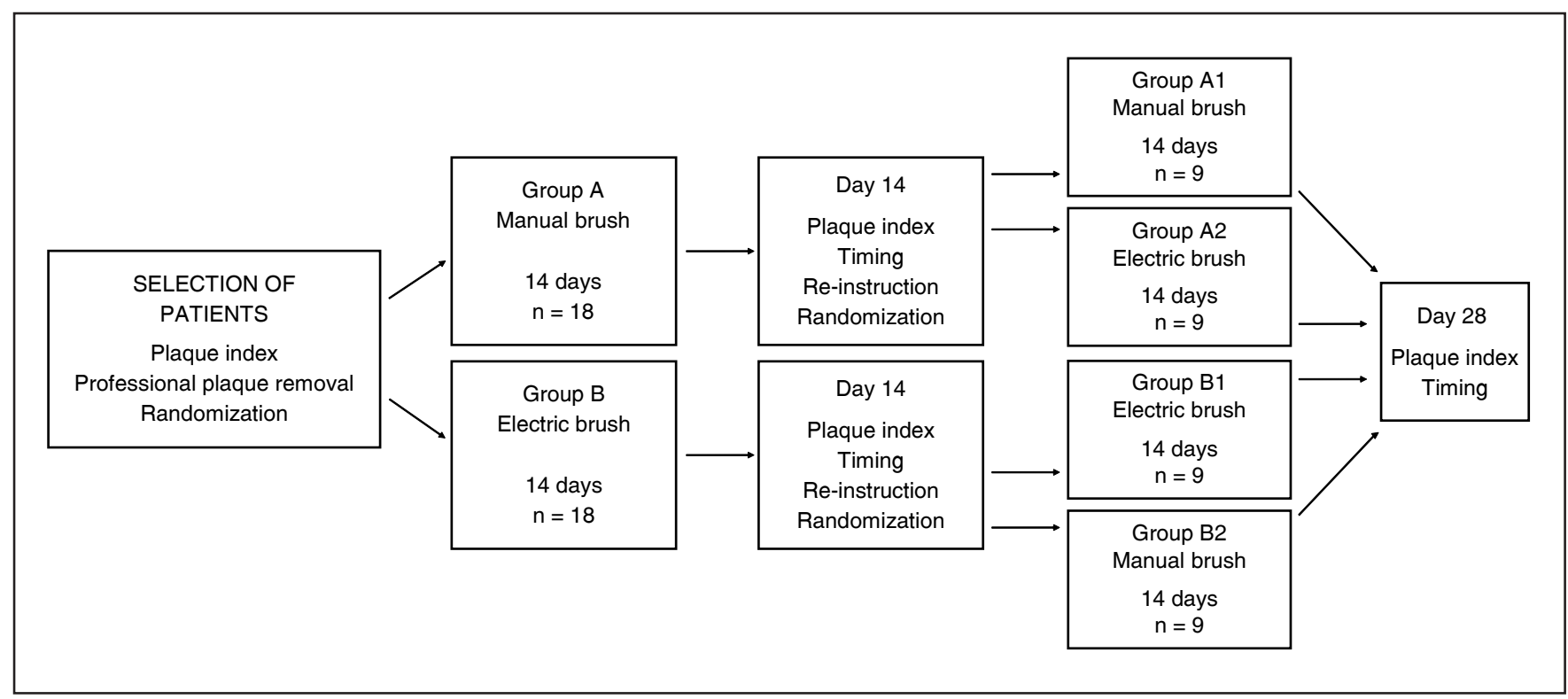

FIGURE 1 - Study design. 
Roscher T, Rösing CK, Gjermo P, Aass AM. Effect of instruction and motivation in the use of electric and manual toothbrushes in periodontal patients. A comparative study. Braz Oral Res 2004;18(4):296-300.

\section{Statistics}

The mean Pl.I for all surfaces was calculated for each observation period. Differences among and within groups were tested using the Student's $t$-test for independent samples and paired samples as appropriate. The chosen $\alpha$-level was 0.05 .

\section{RESULTS}

All subjects completed the treatment regime satisfactorily (100\% compliance). No adverse effects of either brushing regime were recorded. The mean plaque score for each period is shown in Table 1. Differences between the two groups did not reach significance at any time ( $p>0.05)$. The analyses showed large interindividual differences, and that the ability to prevent plaque accumulation improved during the study regardless of the brush used $(p<0.05)$.

The results shown in Table 1 were also analysed in terms of frequency distribution of P1.I scores by Wilcoxon rank sign and Mann-Whitney tests and did not show statistically significant dif- ferences at any time comparing the electric and the manual toothbrush.

The mean brushing time showed no significant differences neither for the brushes nor for the periods (Table 2). However, a tendency to use the electric brush longer than the manual brush was observed.

\section{DISCUSSION}

No significant differences were found between the manual and the electrical brushes. However, all but one group obtained a statistically significant reduction in plaque score after re-instruction. This may indicate that re-instruction is more important than the choice of brush.

Earlier studies comparing manual and electric brushes ${ }^{2,4,8-10,12-14}$ have mostly been related to the general population and not specifically included patients with periodontal treatment needs. In this study, we pictured a clinical situation where the patients are well informed about periodontitis and the impact of plaque removal. This implies that we

TABLE 1 - Mean plaque index (SD) on all surfaces according to brushes used in the two periods.

\begin{tabular}{l|l|l|c}
\hline \hline \multicolumn{1}{c|}{ Experimental groups } & First period & \multicolumn{1}{|c|}{ Experimental groups } & Second period \\
\hline $\begin{array}{l}\text { Group A } \\
\text { Manual }(\mathrm{n}=18)\end{array}$ & $1.10(0.58)^{*} \#$ & $\begin{array}{l}\text { Group A1 } \\
\text { Manual-manual }(\mathrm{n}=9)\end{array}$ & $0.62(0.51)^{*} \#$ \\
\cline { 2 - 4 } & $\begin{array}{l}\text { Group A2 } \\
\text { Manual-electric }(\mathrm{n}=9)\end{array}$ & $0.75(0.43)^{*} \#$ \\
$\begin{array}{l}\text { Group B } \\
\text { Electric }(\mathrm{n}=18)\end{array}$ & $\begin{array}{l}\text { Group B1 } \\
\text { Electric-electric }(\mathrm{n}=9)\end{array}$ & $0.43(0.34)^{*} \#$ \\
\cline { 2 - 4 } & $\begin{array}{l}\text { Group B2 } \\
\text { Electric-manual }(\mathrm{n}=9)\end{array}$ & $0.68(0.43)^{*} \#$ \\
\hline Total & $0.97(0.59)$ & & $0.61(0.43)$ \\
\hline \hline
\end{tabular}

*No statistically significant differences were observed inter-groups in the first or in the second period (independent sample $t$-test, $\alpha=0.05$ ). \#Statistically significant differences were observed intra-groups between the first and second periods (independent and paired sample $t$-test, $\alpha=0.05)$.

TABLE 2 - Mean brushing time in seconds (SD) according to brushes used in the two periods*.

\begin{tabular}{l|c|l|c}
\hline \hline \multicolumn{1}{c|}{ Experimental groups } & First period & \multicolumn{1}{|c}{ Experimental groups } & Second period \\
\hline \multirow{2}{*}{$\begin{array}{l}\text { Group A } \\
\text { Manual }(\mathrm{n}=18)\end{array}$} & $115.28(23.85)$ & $\begin{array}{l}\text { Group A1 } \\
\text { Manual-manual }(\mathrm{n}=9)\end{array}$ & $105.56(34.59)$ \\
\cline { 3 - 4 } & \multirow{2}{*}{$\begin{array}{l}\text { Group A2 } \\
\text { Manual-electric }(\mathrm{n}=9)\end{array}$} & $137.22(36.07)$ \\
\hline \multirow{2}{*}{$\begin{array}{l}\text { Group B } \\
\text { Electric }(\mathrm{n}=18)\end{array}$} & $\begin{array}{l}\text { Group B1 } \\
\text { Electric-electric (n = 9) }\end{array}$ & $129.44(29.31)$ \\
\cline { 3 - 4 } & $132.22(37.39)$ & $\begin{array}{l}\text { Group B2 } \\
\text { Electric-manual }(\mathrm{n}=9)\end{array}$ & $118.89(24.34)$ \\
\hline \hline
\end{tabular}

${ }^{*}$ No statistically significant differences were observed neither intra-groups nor inter-groups (paired and independent $t$-tests, $\alpha=0.05)$. 
Roscher T, Rösing CK, Gjermo P, Aass AM. Effect of instruction and motivation in the use of electric and manual toothbrushes in periodontal patients. A comparative study. Braz Oral Res 2004;18(4):296-300.

expected to have a well-motivated test panel. Thus, the results of this study cannot be extrapolated to the general population.

In most toothbrushing efficacy studies, the outcome is measured as a reduction of plaque mass as compared to baseline. In the present study, we chose not to calculate baseline plaque and assessed the remaining plaque after brushing only, since this is particularly important for periodontal treatment success.

In order to minimize a possible effect of slow and quick plaque formers, the patients brushed immediately before scoring. Brushing time was recorded without the patients' awareness and showed that they used approximately the recommended time for all tests (120 sec., Table 2).

To compensate for interindividual differences, we chose a cross-over design. This also makes it possible for us to calculate the impact of the second oral hygiene instruction separately from the effect of the type of brush.

The improvement obtained from 2 to 4 weeks irrespective of the brush used could be an effect of the familiarization with the product. However,

\section{REFERENCES}

1. Aass AM, Gjermo P. Comparison of oral hygiene efficacy of one manual and two electric toothbrushes. Acta Odontol Scand 2000;58:166-70.

2. Ainamo J, Hormia M, Kaunisaho K, Sorsa T, Suomalainen K. Effect of manual versus powered toothbrushes [abstract 2329]. J Dent Res 1991;(Suppl):557.

3. Axelson P, Lindhe J. Effect of controlled oral hygiene procedures on caries and periodontal disease in adults. J Clin Periodontol 1978;5:133-51.

4. Barnes CM, Weatherford TW $3^{\text {rd }}$, Menaker L. A comparison of the Braun Oral-B Plaque Remover (D5) electric and a manual toothbrush in affecting gingivitis. J Clin Dent 1993;4:48-51.

5. Garmyn P, van Steenberghe D, Quirynen M. Efficacy of plaque control in the maintenance of gingival health: plaque control in primary and secondary prevention. In: Lang NP, Attström R, Löe H, editors. Proceedings of the European Workshop on Mechanical Plaque Control. Berlin: Quintessence; 1998. p. 107-20.

6. Greene JC. World workshop in periodontics. In: Ramfjord SP, Kerr DA, Ash MM, editors. Ann Arbor, MI: American Academy of Periodontology; 1966. p. 399-443.

7. Löe H, Silness J. Periodontal disease in pregnancy. I. Prevalence and severity. Acta Odontol Scand 1963;21:533-51. the effect was also seen in the cross-over part of the study. The Hawthorne effect ${ }^{11}$ (which could also be expected) is usually more apparent in the first phase of a study. Thus, our explanation that this improvement is due to re-instruction seems warranted.

The results showed minimal differences between the brushes in the ability to prevent plaque accumulation. These differences may not be considered of clinical significance and did not yield statistical significance. As a consequence, the patient's interest should be decisive for the choice of brush. We did not ask for preference in our study, but earlier studies indicate that patients prefer the electrical brush due to a subjective feeling of better cleaning ability ${ }^{1}$.

\section{CONCLUSION}

In conclusion, for individuals with periodontal disease, professional advice and instruction and re-instruction seem more important in order to obtain good plaque control than the choice of toothbrush.

8. Murray PA, Boyd RL, Robertson PB. Effect of periodontal status of rotary electric toothbrushes $v s$. manual toothbrushes during periodontal maintenance. II. Microbiological results. J Periodontol 1989;60:396-401.

9. Niemi ML. Gingival abrasion and plaque removal after toothbrushing with an electric and a manual toothbrush. Acta Odontol Scand 1987;45:367-70.

10. Quigley GA, Hein JW. Comparative cleansing efficiency of manual and power brushing. J Am Dent Assoc 1962;65:26-9.

11. Robertson PB, Armitage GA, Buchanan SA, Taggart EJ. The design of trials to test the efficacy of plaque control agents for periodontal diseases in humans. J Dent Res 1989;68:1667-71.

12. Stoltze K, Bay L. Comparison of a manual and a new electric toothbrush for controlling plaque and gingivitis. J Clin Periodontol 1994;21:86-90.

13. van der Weijden GA, Danser MM, Nijboer A, Timmerman $\mathrm{MF}$, van der Velden $\mathrm{U}$. The plaque-removing efficacy of a reciproque rotating toothbrush [abstract 2328]. J Dent Res 1991;(Suppl):557.

14. Walsh M, Heckman B, Leggott P, Armitage G, Robertson PB. Comparison of manual and power toothbrushing, with and without adjunctive oral irrigation, for controlling plaque and gingivitis. J Clin Periodontol 1989;16:419-27.

Received for publication on Mar 01, 2004

Sent for alterations on Aug 02, 2004

Accepted for publication on Sep 27, 2004 